\title{
ВПРОВАДЖЕННЯ ЕЛЕКТИВНОГО КУРСУ "КЛІНІЧНА ПАТОФІЗІОЛОГІЯ” У НАВЧАЛЬНИЙ ПРОЦЕС СТУДЕНТІВ МЕДИЧНОГО ФАКУЛЬТЕТУ НА КАФЕДРІ ФУНКЦІОНАЛЬНОЇ ДІАГНОСТИКИ ТА КЛІНІЧНОЇ ПАТОФІЗІОЛОГІЇ ТДМУ ІМЕНІ І. Я. ГОРБАЧЕВСЬКОГО
}

\author{
М. І. Марущак, С. В. Дзига, О. В. Бакалець, Н. Б. Бегош \\ ДВНЗ “Тернопільський держсавниймедичний університет імені І. Я. Горбачевського МОЗ Украйни”
}

\section{IMPLEMENTATION OF ELECTIVE COURSE “CLINICAL PATHOPHYSIOLOGY” IN THE EDUCATIONAL PROCESS OF STUDENTS OF MEDICAL FACULTY AT THE DEPARTMENT OF FUNCTIONAL DIAGNOSTICS AND CLINICAL PATHOPHYSIOLOGY OF TSMU BY I. YA. HORBACHEVSKY}

\author{
M. I. Marushchak, S. V. Dzyha, O. V. Bakalets, N. B. Behosh \\ SHEI “Ternopil State Medical University by I. Ya. Horbachevsky of MPH of Ukraine”
}

\begin{abstract}
У статті висвітлено особливості викладання клінічної патофізіології для студентів медичного факультету відповідно до кредитно-модульної системи організації навчального процесу.
\end{abstract}

\begin{abstract}
The article adduces the peculiarities of the Clinical Pathophysiology teaching for students of medical faculty according to the norms of the credit-transfer educational system.
\end{abstract}

Вступ. На сучасному етапі широке впровадження сучасних технологій та жорсткої конкуренції вимагає якісної медичної освіти, яка передбачає формування у майбутніх лікарів клінічного мислення, вміння ефективно вирішувати їхні професійні завдання на основі патофізіологічного аналізу даних фізикальних, лабораторних та інструментальних методів дослідження, призначати адекватне лікування $[1,2]$.

3 цією метою на кафедрі функціональної діагностики та клінічної патофізіології ТДМУ ім. І. Я. Горбачевського створено елективний курс клінічної патофізіології для студентів 6 курсу медичного факультету. Слід зазначити, що в даний час багато нових фактів патофізіології отримується шляхом використання новітніх методів дослідження. Звідси $є$ неминучим відставання теоретичного змісту клінічної практики від сучасних уявлень про патогенез та патогенетичну терапію, що зумовлює необхідність викладання студентам старших курсів клінічної патофізіології в рамках спеціального або елективного курсів. У процесі вирішення поставлених завдань, під час аналізу конкретної клінічної ситуації виявляються найбільш ймовірні причини, фактори ризику та ключові ланки патогенезу захворювань. 3 урахуванням цього формулюються і обгрунтовуються стратегія, алгоритми і програми діагностичного пошуку, лікування та профілактики патології людини [2,3].

Основна частина. Вивчення даної дисципліни базується, в першу чергу, на теоретичному курсі патологічної фізіології, а також курсах клінічних дисциплін. Метою вивчення клінічної патофізіології є застосування знань, отриманих студентами при вивченні базової патологічної фізіології, у практичній роботі в умовах стаціонару. Розуміння основних закономірностей виникнення та перебігу патологічних процесів, що відбуваються в організмі, характеру компенсаторних механізмів, що забезпечують збереження функції ураженого органа, $є$ необхідним для обгрунтування та вибору диференційованих підходів у лікуванні пацієнта [2, 4].

При вивченні даної дисципліни ставляться такі завдання:

1. Поглиблювати та систематизувати знання студентів у сфері клінічно значимих розділів загальної патофізіології та найактуальніших тем патофізіології органів та систем. 
2. Ознайомлювати студентів 3 найсучаснішими $\mathrm{i}$ передовими досягненнями патофізіологічної науки.

3. Виявляти зв' язок патогенезу захворювання з його клінічними проявами і змінами лабораторних та інструментальних показників.

4. Проводити клініко-патофізіологічний аналіз синдромів, правильно інтерпретувати результати лабораторних та інструментальних методів дослідження на основі розуміння того, що відбувається у хворому організмі.

5. Обгрунтувати принципи терапії відповідно до сучасних уявлень про причини та механізми розвитку захворювання.

Відповідно до навчального плану викладання клінічної патофізіології для студентів медичного факультету здійснюється на 6 курсі у 11-12 семестрах у рамках елективного курсу.

На кафедрі розроблені навчально-методичні матеріали у вигляді робочої програми з дисципліни, методичних вказівок до практичних занять і для самостійної роботи студентів, матеріалів для підготовки студентів до практичних занять, створено банк тестових завдань для проведення щоденного альтернативного дистанційного контролю знань студентів за системою "Moodle", а також ряд ситуаційних задач, електронний варіант таблиць та відеофільмів, що полегшують сприйняття матеріалу.

Засвоєння дисципліни здійснюється під час практичних занять та самостійної роботи студентів.

Практична частина заняття передбачає індивідуальну роботу біля ліжка хворого: студент проводить опитування по органах і системах, збирає анамнез захворювання, життя, проводить об'єктивне обстеження у присутності викладача з обов' язковим дотриманням відповідних комунікативних алгоритмів. Завданнями практичної роботи є наступні: згрупувати виявлені симптоми в синдроми; провести патофізіологічний аналіз виділених синдромів, визначивши їх головні патогенетичні механізми; виділити про-

\section{Лiтература}

1. Гоженко А. И. Роль и пути совершенствования преподавания патофизиологии в высшей медицинской школе / А. И. Гоженко // Бюлетень VIII читань ім. В. В. Підвисоцького, 28-29 травня 2009 року. - Одеса, 2009. - С. 30-31.

2. Международный симпозиум 2009 г. по проблемам преподавания патофизиологии // Вестник С.-Петербургск. ун-та. Сер. 11 : Медицина. - 2010. - № 1. - С. 250-253.

3. Гончаров С. М. Кредитно-модульна система організації навчального процесу у світлі Болонської декларації: документи, матеріали, факти / С. М. Гончаров. - Рівне : відний синдром, за яким провести диференційну діагностику захворювання; сформулювати попередній діагноз; скласти план обстеження та лікування конкретного хворого, виходячи 3 аналізу причин, механізмів розвитку хвороби, їі симптомів $[3,5]$.

Під час дискусійного обговорення студенти проводять клінічний розбір пацієнтів, а також змодельованих клінічних ситуацій. Основний акцент робиться на патофізіологічному обгрунтуванні симптомів та клініко-лабораторних синдромів, що виникають у конкретного хворого, а також диференційованому призначенні методів функціональної, лабораторної та інструментальної діагностики, обгрунтуванні адекватного етіотропного, патогенетичного і симптоматичного лікування.

3 метою підвищення творчої активності студенти працюють над темами, які винесені на самостійне опрацювання, що сприяє розвитку в них навичок роботи з літературою, вчить узагальнювати та використовувати отримані знання. Значну роль при цьому відіграють інформаційні технології, серед яких - використання доступних Інтернет-ресурсів, в тому числі Web-сторінки університету, що була створена 3 метою оптимізації навчального процесу.

Ступінь засвоєння навчального матеріалу оцінюється в кінці практичного заняття з використанням відповідних контролюючих програм або шляхом тестового контролю в системі "Moodle", який здійснюється напередодні практичного заняття.

Висновок. Метою вивчення клінічної патофізіології студентами 6 курсу медичного факультету є формування в них творчого підходу, лікарського клінічного мислення. Це базується на розумінні патофізіологічних механізмів розвитку окремих симптомів та синдромів, що виникають при патології внутрішніх органів, вмінні обгрунтувати принципи терапії відповідно до сучасних уявлень про причини та механізми розвитку захворювання.

НУВГП, 2004. - 34 c.

4. Орлов С. Н. Что такое патофизиология? Размышления участников всемирного форума патофизиологов в Монреале / С. Н. Орлов, Л. П. Чурилов, Ю. И. Строев // Патол. физиол. эксперим. терап. -2011. - № 2. - С. 3-12.

5. Удосконалення самостійної роботи студентів - важлива складова в реалізації галузевого державного стандарту медичної освіти / Г. В. Дзяк, Т. О. Перцева, Г. В. Горбунова, Н. В. Ліхолетова // Медична освіта. - 2004. - № 1. - С. 15-16. 